\title{
SYNTHESIS OF METHANOL FROM METHANE IN CAVITATION FIELD
}

\author{
Oleksii Tselishchev ${ }^{1}$, Ayodeji ljagbuji ${ }^{1}$, Maryna Loriia ${ }^{1,}{ }^{*}$, Vanadii Nosach $^{2}$
}

https://doi.org/10.23939/chcht12.01.069

\begin{abstract}
Methanol synthesis was achieved by a free-radical mechanism of the compounding reaction of methane and hydroxyl radical. Experiments were performed by feeding methane and hydrogen-peroxide into a cavitation field. The major reaction products were methanol and water molecules. The calculated degree of methane conversion equals to $\sim 10 \%$.
\end{abstract}

Keywords: methane activation, hydroxyl radical, methyl radical, cavitation, methanol synthesis.

\section{Introduction}

Conventional technologies for methanol production involve steam methane reforming (SMR) to syngas at high temperature (1073-1273 K) and moderate pressure (4 MPa), followed by syngas conversion into methanol by passing it through co-precipitated copper/zinc-oxide $(\mathrm{Cu} / \mathrm{ZnO})$ catalysts at low temperature $(493-553 \mathrm{~K})$ and high pressure (5-8 MPa) [1]. However, the overall efficiency of methanol synthesis via this indirect way is greatly undermined by thermodynamics, and high-theoretical conversion into carbon monoxide due to limitations imposed by the reaction equilibrium and low heat efficiency. Thus, it is considered not cost-effective $[2,3]$.

A long-term research of the direct conversion of methane into methanol (without syngas formation) has received considerable attention by scientists, researchers, and technologists [4-7]. Being part of green-house gases (GHG), methane also contributes to global warming. However, owing to its low $\mathrm{C}-\mathrm{H}$ ratio and high calorific value, it has an enormous potential as an ideal fuel in the continuing efforts to minimize the local and global environmental impact of energy use [2], and as a feedstock for chemical synthesis. Therefore, it is desirable to convert methane into liquid transportable fuels such as methanol, as it retains most of methane energy,

\footnotetext{
${ }^{1}$ Volodymyr Dahl East Ukrainian National University, 59a, Tsentralny Prosp., 93400 Severodonetsk, Ukraine,

${ }^{2}$ JSC «ORGCHIM», 32, Hvardiisky Prosp., 93411 Severodonetsk, Ukraine *atp01@ukr.net

(C) Tselishchev O., Ijagbuji A., Loriia M., Nosach V., 2018
}

contributes to safe transportation and cleans environment using economically viable and easily accessible resources. As demonstrated in reports [7-11], hydroxyl radical has proven to be an effective activator of alkane molecules with quite low activation energy calculated to be between $8-15 \mathrm{~kJ} / \mathrm{mol}$ [11]. Although least explored, one of the most viable means of obtaining hydroxyl radical, which can be implemented on an industrial production scale is dynamic cavitation of the hydrogen peroxide solution [12-17], being potential high energy oxidant, green, relatively cheap, easy to handle, and for the fact that its oxidation produces only water and oxygen as by-products [18].

It has been reported in [19] that propane-butane gas in the presence of abundant and inexpensive reactants such as water and hydrogen peroxide may be converted into methanol strictly in a cavitation reactor. Moreover, the proposed unit is characterized by a number of advantages such as: (i) a small number of devices is required, low metal and energy consumption is observed; (ii) the overall cavitation process can be performed in a single-unit apparatus, and (iii) the refined products are immiscible. Therefore, the objectives of this research are to determine the main pre-conditions for the reactor design, to evaluate the efficiency of hydroxyl radical obtaining, and to carry out the experimental procedure for conversion of methane into methanol using a cavitation reactor.

To the best of our knowledge, the direct conversion of methane into methanol in a cavitation reactor has not been previously reported in literature, hence, this is considered to be an important research.

\section{Experimental}

To justify the theoretical concepts, the experimental studies on methane conversion into methanol using a microfabricated cavitation reaction vessel (Fig. 1), as well as a mathematical modeling (Fig. 2) of the technological process were performed [20]. The present study is a step ahead in the same direction as it was designed after careful analysis of the results of previous studies [19]. In addition, the influence of changes in the process 
parameters on the degree of methane conversion, and methanol yield was observed. To ensure subsonic flow, the nozzle diameter, the linear flow rate, and the pressure drop of the reaction mixture through the nozzle were determined. The output process parameters are methanol concentration at the reactor output, and the degree of methane conversion into methanol. The calculation of parameters for the cavitation reactor was performed by using MAPLE 14 software package.

The perturbing parameters include the outlet pressure, hydrogen peroxide concentration in the aqueous solution, the ratio of methane to the hydrogen peroxide solution. The schematic diagram for the direct conversion of methane into methanol is illustrated in Fig. 2.

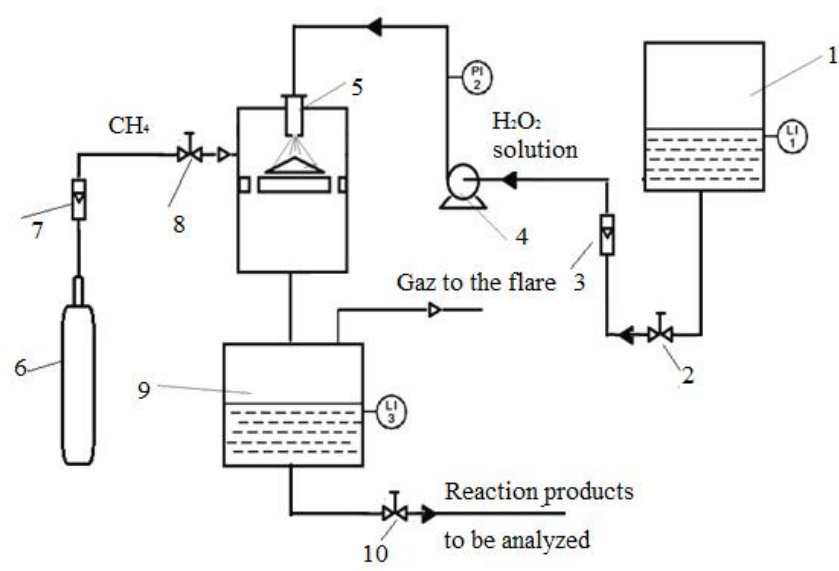

Fig. 1. Scheme of the laboratory unit for conversion of methane into methanol in a cavitation flow reactor system: vessel for hydrogen peroxide (1); control valves $(2,8,10)$; rotameters $(3,7)$; high pressure pump (4); cavitation reactor $(5)$; cylinder with carbohydrate gas (6) and tank for reaction products (9)

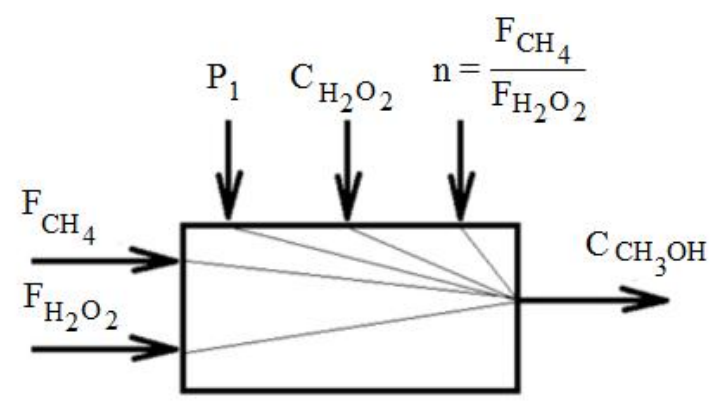

Fig. 2. Information and logical scheme of direct cavitation conversion of methane into methanol

As follows from the analysis, the direct conversion process of methane into methanol is one-dimensional. To study this process, it is necessary to stabilize the regulating and perturbing parameters in order to bring the reaction process to a state in which there exists no alteration in methanol concentration at the reactor outlet. Thereafter, it is necessary to change only one of these parameters within the studied range, fixing the value of the outlet parameter.

The experiment was conducted as follows: $50 \mathrm{ml}$ of hydrogen peroxide solution with pre-determined concentration (0-20\%) using a high-pressure pump was fed into the cavitation reactor at the flow rate of $3.5 \mathrm{l} / \mathrm{min}$. The flow rate of methane varied between 0 to $0.1 \mathrm{Nm}^{3} / \mathrm{min}$. Prior to the commencement of the experiment, the chromatographic analysis of samples was performed using a liquid chromatograph "Crystal 2000" and it was affirmed that the total content of methane gas in the cylinder was 96-98\%. Reaction temperature was between 530-555 K. The reactor inlet pressure (before nozzle) was fluctuated at a range of 0-30 MPa. Control valves $(2,8)$ were provided to manipulate the flow rates, temperature, and pressure of liquid through the main lines; a rotameter (4) was provided to measure the inlet pressure $\left(P_{1}\right)$ and the fully recovered downstream pressure $\left(P_{2}\right)$; and a nozzle (3) was provided to control the direction of the fluid flow.

The reaction products were collected in a tank (9), and finally separated into their individual components, whereas any unreacted gas or gaseous reaction products may either be flared, or recycled back into the reactor. The reaction products were then subjected to a chromatographic analysis.

\section{Results and Discussion}

Aqueous solution of hydrogen peroxide under the action of cavitation dynamic (i.e. rapid pressure change or high energy density between $1-10^{18} \mathrm{~kW} / \mathrm{m}^{3}$ ) thermally decomposes into two hydroxyl radicals. Furthermore, the energy released under the same reaction condition is sufficient enough to break hydrocarbon chains and even upgrade crude. Upon the interaction of the generated hydroxyl radical with a methane molecule, the hydroxyl radical reaction proceeds by hydrogen atom abstraction from the $\mathrm{C}-\mathrm{H}$ bond of methane to form methyl radical and water molecule. The dependence graph of methanol concentration as a result of cavitation conversion on varied pressure at a methane flow rate of $100 \mathrm{l} / \mathrm{min}$, and on varied concentration of hydrogen peroxide solution at 3.5 1/min, is depicted in Fig. 3.

At nozzle pressure below $9 \mathrm{MPa}$ in the reaction system, methanol concentration in condensate was not observed. This may be attributed to the fact that at reactor inlet pressure lower than $9 \mathrm{MPa}$, the flow rate of the hydrogen peroxide solution was below $140 \mathrm{~m} / \mathrm{s}$ - the required speed for the cavitation process to proceed - and consequently decomposition of the hydrogen peroxide solution into hydroxyl radicals was not observed. 


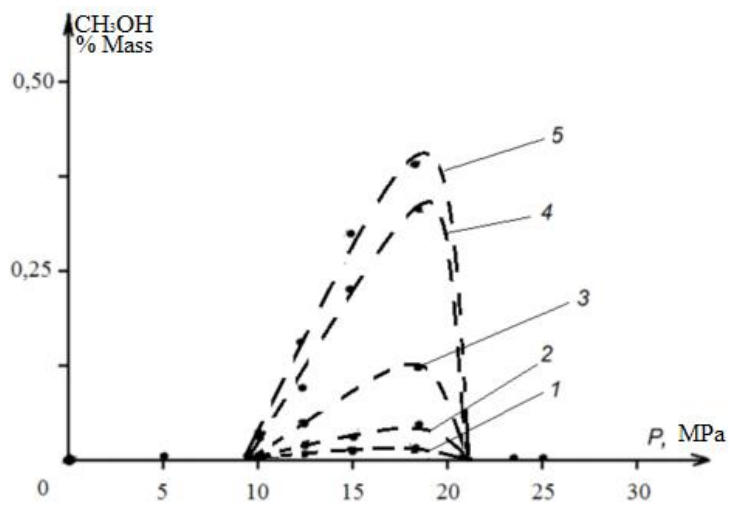

Fig. 3. Dependence graph of methanol concentration on pressure at different hydrogen peroxide concentrations $(\%)$ : $0(1) ; 3(2) ; 5$ (3); 10 (4) and 20 (5)

At pressure between 10-20 MPa the increase in methanol concentration was observed with the highest methanol yield $\left(Y_{\text {methanol }}=0.4 \%\right)$ recorded at $19 \mathrm{MPa}$. Above $20 \mathrm{MPa}$, exactly opposite effect was observed in contrast to yields of methanol. This is due to the fact that under the said condition the boiling process commences. At nozzle pressure between $23-25 \mathrm{MPa}$, the hydrogen peroxide solution is converted into steam. Therefore, neither decomposition of hydrogen peroxide into hydroxyl radicals, nor methanol formation did occur. Further increase in the inlet pressure above $25 \mathrm{MPa}$ does not lead to any noticeable influence on the yield of methanol irrespective of the applied concentration of the hydrogen peroxide solution into the system. The calculated degree of conversion of natural gas into methanol is $\sim 10 \%$. Given the fact that changes in the initial gas do not occur, the technological scheme was particularly designed to ensure that any unreacted gas may be recycled back into the reactor. Results of the direct cavitation conversion of methane into methanol using different concentrations of hydrogen peroxide solution at flow rate of $3.5 \mathrm{l} / \mathrm{min}$, natural gas flow rate of $0.1 \mathrm{Nm}^{3} / \mathrm{min}(4.46 \mathrm{~mol} / \mathrm{min})$ and nozzle pressure of $19 \mathrm{MPa}$ are shown in Table 1.

The experimental results in Table 1 show that the amount of decomposed hydrogen peroxide as a result of cavitation significantly exceeds the amount of methanol formed. The dependence of the degree of conversion on hydrogen peroxide illustrated in Fig. 4 shows that increasing hydrogen peroxide concentration above $20 \%$ is unsuitable because it does not necessarily result in an increased degree of conversion, but instead it substantially increases the cost of the reaction process and its explosion potential. In our point of view, this may be attributed to the possibility of hydroxyl radical to react with the reactor material as evident by corrosion traces on the inner walls of reactor. Therefore, it can be argued that the use of the hydrogen peroxide solution with the concentration between $10-20 \%$ is optimal for the cavitation conversion process of methane into methanol. It is worth mentioning that not all hydrogen peroxide solutions decompose upon exposure to cavitation. However, the solution may be further re-used after extraction of methanol.

The degree of methane conversion $(K)$ is defined as the ratio of the number of moles of methanol formed during the conversion to the number of moles of methane entering the reactor. This relationship is shown in Fig. 4.

If the raw material was used by PBG, an experiment was conducted in the same manner as in the previous case. The dependence of the concentration of methanol, formed as a result of cavitation PBG conversion on the pressure, at which the hydrogen peroxide solution is fed in the reactor, is shown in Fig. 5.

Analyzing the given dependencies, one can make such conclusions. At a pressure lower than $9 \mathrm{MPa}$, no changes occur in the hydrogen peroxide solution and in PBG. The reason is that at a pressure lower than $9 \mathrm{MPa}$ at the nozzle inlet, the flow rate in the nozzle does not exceed $140 \mathrm{~m} / \mathrm{s}$, that is at the nozzle outlet the conditions for the cavitation process are not attained. And hence, decomposition of hydrogen peroxide to hydroxyl radicals does not occur; consequently, there is no formation of methanol by the procedure described in Section 2 of the mechanism. When the pressure is increased to above $9 \mathrm{MPa}$ at the nozzle inlet, methanol appears in the reaction products. Concentration of methanol formed due to cavitation conversion of PBG increases with increasing pressure up to 19-20 MPa. The reason is that at the nozzle outlet, the conditions for cavitation are created and this process takes place more fully. Further increase in pressure leads to the opposite effect. Concentration of methanol formed as a result of conversion decreases, and at the pressure of more than $21 \mathrm{MPa}$, concentration of methanol formed equals to 0 . The reason is that during throttling at such pressure, the liquid boils, and at the pressure of more than $21 \mathrm{MPa}$, all the flow of the hydrogen peroxide solution is converted into the steam. The maximum concentration of methanol achieved was about $0.5 \%$ during the experimental investigations.

Methanol outlet is also affected by the concentration of hydrogen peroxide in the aqueous solution. As follows from the experimental data (Table 2), increasing the hydrogen peroxide concentration in the initial solution fed to the cavitation reactor up to $20 \%$ leads to a significant increase in concentration of methanol formed. With further increase in the hydrogen peroxide concentration in the initial solution, increase in the methanol concentration is not so noticeable. Thus, it can be argued that use of the hydrogen peroxide solution with the concentration of $10-20 \%$ is optimal. Given the fact that not all hydrogen peroxide is decomposed as a result of cavitation processing, the solution can be reused after removal of methanol. The degree of PBG conversion into methanol is also low and equals to $10 \%$. 
Table 1

The degree of methane conversion into methanol (per 1 minute of unit work)

\begin{tabular}{|c|c|c|c|c|c|c|}
\hline $\begin{array}{c}\text { Concentration of } \\
\text { outlet } \mathrm{H}_{2} \mathrm{O}_{2} \\
\text { solution }\end{array}$ & $\begin{array}{c}\text { Methanol } \\
\text { concentration at } \\
\text { the unit outlet, \% }\end{array}$ & $\begin{array}{c}\text { Mass of } \\
\text { methanol } \\
\text { formed, } \mathrm{g}\end{array}$ & $\begin{array}{c}\text { Mass of } \\
\text { methanol } \\
\text { formed, mol }\end{array}$ & $\begin{array}{c}\text { Mass of } \\
\text { decomposed } \\
\mathrm{H}_{2} \mathrm{O}_{2}, \mathrm{~g}\end{array}$ & $\begin{array}{c}\text { Consumed } \\
\mathrm{H}_{2} \mathrm{O}_{2}, \%\end{array}$ & $\begin{array}{c}\text { Degree of } \\
\text { methane } \\
\text { conversion }(K) \\
\text { into methanol, } \%\end{array}$ \\
\hline 0 & 0.01 & 0.34 & 0.01 & - & - & 0.24 \\
\hline 3 & 0.03 & 1.05 & 0.03 & 3.8 & 3.6 & 0.74 \\
\hline 5 & 0.12 & 4.20 & 0.13 & 9.7 & 5.5 & 2.95 \\
\hline 10 & 0.35 & 12.25 & 0.38 & 17.3 & 4.9 & 8.60 \\
\hline
\end{tabular}

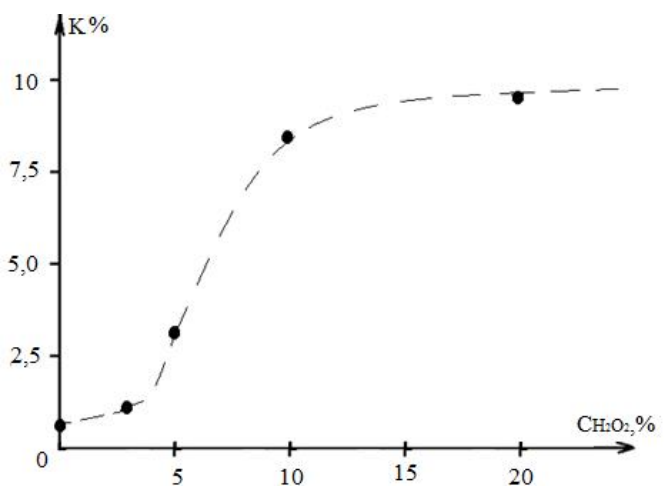

Fig. 4. Dependence of degree of methane conversion on the concentration of the hydrogen peroxide solution

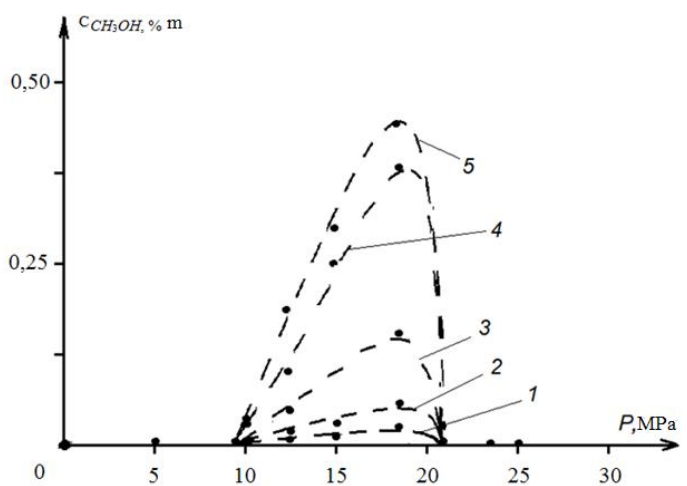

Fig. 5. Dependence of concentration of methanol formed on pressure at different hydrogen peroxide concentrations $(\%)$ : 0 (1); 3 (2); 5 (3); 10 (4) and 20 (5) [14]

PBG consumption - 100 l/min; consumption of hydrogen peroxide solution $-3.5 \mathrm{l} / \mathrm{min}$

Table 2

The degree of conversion into methanol PBG (per 1 minute of unit work)

\begin{tabular}{|c|c|c|c|c|c|}
\hline $\begin{array}{c}\text { Concentration of } \\
\text { stock } \mathrm{H}_{2} \mathrm{O}_{2} \text { solution }\end{array}$ & $\begin{array}{c}\text { Concentration of } \\
\text { methanol at the } \\
\text { unit outlet, } \%\end{array}$ & $\begin{array}{c}\text { Mass of methanol } \\
\text { formed, } \mathrm{g}\end{array}$ & $\begin{array}{c}\text { Mass of } \mathrm{H}_{2} \mathrm{O}_{2} \\
\text { decomposed, } \mathrm{g}\end{array}$ & $\begin{array}{c}\text { Consumed } \mathrm{H}_{2} \mathrm{O}_{2}, \\
\%\end{array}$ & $\begin{array}{c}\text { Degree of PBG } \\
\text { conversion into } \\
\text { methanol, } \%\end{array}$ \\
\hline 0 & 0.01 & 0.34 & - & - & 0.25 \\
\hline 3 & 0.06 & 2.10 & 3.6 & 3.4 & 1.46 \\
\hline 5 & 0.15 & 5.25 & 9.5 & 5.4 & 3.65 \\
\hline 10 & 0.40 & 14.00 & 17.5 & 5.0 & 9.72 \\
\hline 20 & 0.46 & 16.10 & 18.7 & 2.7 & 11.18 \\
\hline
\end{tabular}

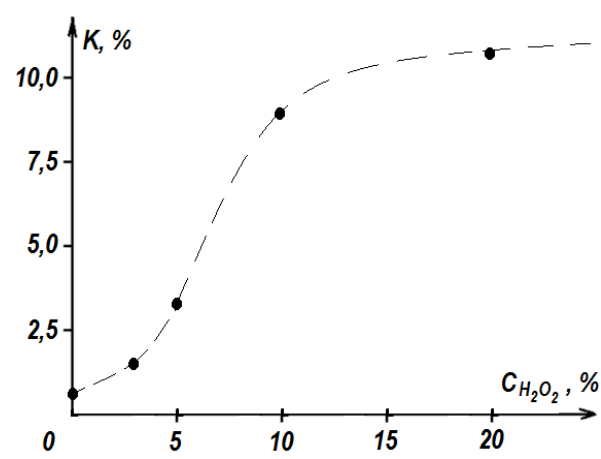

Fig. 6. The dependence of the degree of PBG conversion into methanol on the concentration of hydrogen peroxide in the aqueous solution
As follows from the analysis of experimental data, the amount of hydrogen peroxide, disintegrated as a result of cavitation, significantly exceeds the amount of methanol formed. However, the amount of methanol formed as a direct consequence of cavitation PBG conversion into methanol, almost 1.1 times greater than the emissions conversion. The reason is that the relationship of $\mathrm{CH}$ methane is a stronger bond in the same propane or butane. Analyzing the results of studies of direct cavitation PBG conversion into methanol, systematized in Table 2, we can construct dependence of conversion PBG on the concentration of hydrogen peroxide in the initial aqueous solution. The degree of conversion $K$ is defined as the ratio of the number moles of methanol formed during the 
conversion to the number of moles PBG entering the reactor. This relationship is shown in Fig. 6.

It should be noted that the degree of conversion into methanol PBG is almost 1.1 times higher than the level of GHG conversion into methanol under similar conditions. Analyzing the dependence, which is shown in Figure 6, it can be argued that the use of the hydrogen peroxide solution with the concentration of $10-20 \%$ is optimal. Taking into account that not all hydrogen peroxide decomposes due to a cavitation processing, this solution can be reused after extraction of methanol.

\section{Conclusions}

The technology for the direct cavitation conversion of methane into methanol based on cavitation of hydrogen peroxide solution has been experimentally investigated. The following important conclusions can be established from the present study:

- hydroxyl radical (generated via dynamic cavitation and decomposition of the hydrogen peroxide solution) is an effective activator of methane molecules;

- at flow rate of $140 \mathrm{~m} / \mathrm{s}$ and above, the pressure at the nozzle reaches a point where cavitation starts. This speed allows calculating the nozzle diameter $(0.7-1 \mathrm{~mm})$;

- the calculated degree of methane conversion into methanol equals to zero when hydrogen peroxide is absent in the cavitation flow;

- the optimal parameters for direct cavitation conversion of methane into methanol, providing $10 \%$ conversion, obtained at $\mathrm{CH}_{4} / \mathrm{H}_{2} \mathrm{O}_{2}$ molar ratio $=1: 1$, $T=555 \mathrm{~K}, P=19 \mathrm{MPa}$; the hydrogen peroxide concentration of $20 \%$;

- the cavitation reactor for processing gaseous and liquid hydrocarbons allows creating three cavitation zones;

- the processing unit for the cavitation conversion of methane into methanol is characterized by a relatively small number of devices, low material-and metal consumption.

Based on the obtained results, the proposed methodology in this report is deemed to be cost effective, ecologically friendly, and can also serve as a useful guide to develop an industrial plan for the large scale methane conversion into methanol.

\section{Acknowledgements}

The authors would like to express their profound gratitude to Prof. M. A. Glikin, Department of Technology of Fuels \& Organic Products Synthesis, Volodymyr Dahl East Ukrainian National University for the reviewing assistance rendered in this work.

\section{References}

[1] Imperial Chemical Industries (ICI). Methanol Synthesis Technology, London 1966.

[2] Dlugokencky E., Masarie K., Lang P. et al.: Nature, 1998, 393,

447. https://doi.org/10.1038/30934

[3] Crabtree R.: Chem. Rev., 1995, 95, 987.

https://doi.org/10.1021/cr00036a005

[4] Rozovskyy A., Lin G: Teoreticheskie Osnovy Processa Sinteza Metanola. Khimiya, Moskva 1990.

[5] Shilov A., Shul'pin G: Activation and Catalytic Reactions of Saturated Hydrocarbons in the Presence of Metal Complexes [in:]

Parkins A. (Ed.), Applied Organometallic Chemistry. Kluwer Academic Publishers, Dordrecht 2000.

[6] Rudakov E.: Elektroliz v Neorganicheskoi Khimii. Naukova Dumka, Kiev 1985.

[7] Arutyunov V., Krylov E.: Uspekhi Khimii, 2005, 74, 1216. https://doi.org/10.1070/RC2005v074n12ABEH001199

[8] Tselishchev A., Zakharov I., Loriya M. et al.: Voprosy Khim. i Khim. Technol., 2012, 2, 39.

[9] Loriya M., Ijagbuji A., Tselischev A. et al.: Adv. Mat. Res., 2013, 660, 51. https://doi.org/10.4028/www.scientific.net/AMR.660.51

[10] Tselishchev A., Lòriya M., Zakharov I.: Visnyk Kiev Polytech. Inst., 2011, 65, 111.

[11] Zakharov I., Ijagbuji A., Tselischev A. et al.: J. Environ. Chem. Eng., 2015, 3, 405. https://doi.org/10.1016/j.jece.2014.08.008

[12] Zamilov M., Godin S.: Quant. Potent. Corp., 2012, 1.

[13] Wang X., Wang J., Guo W. et al.: J. Hazard. Mater, 2009, 169, 486 - 491. https://doi.org/10.1016/j.jhazmat.2009.03.122

[14] Shah Y., Pandit A., Moholkar V.: Cavitation Reaction Engineering. Kluwer Academic/Plenum Publ., New York 1999. https://doi.org/10.1007/978-1-4615-4787-7

[15] Tselischev A., Nosach V., Koshovets M. et al.: Pat. UA 104811 MEI G05D 19/00, Publ. Febr. 25, 2016.

[16] Tselishchev A., Zakharov I., Loriya M. et al.: Khim. Promysh. Ukrainy, 2014, 121, 39.

[17] Tselischev A., Nosach V., Koshovets M. et. al.: Pat. UA 105427 MEI S10G 2/100, Publ. March 25, 2016.

[18] Jiang H., Gong H., Yang Z. et al.: React. Kinetic Catal. Lett., 2002, 75, 315. https://doi.org/10.1023/A:1015207214720

[19] Tselishchev A., Lòriya M., Eliseev P. et al.: East. Eur. J. Enterp. Technol., 2015, 6, 48.

[20] Tselischev A., Elissev P., Lòryia M. et al.: Matematicheskoe Modelirovanie Technologicheskikh Protsessov. Vostochnoukr. Nats. Univ., Lugansk 2011.

Received: February 09, 2017 /Revised: February 27, 2017 / Accepted: June 01, 2017

\section{СИНТЕЗ МЕТАНОЛУ 3 МЕТАНУ В КАВІТАЦІЙНОМУ ПОЛІ}

Анотація. Розроблений спосіб синтезу метанолу за вільно-радикальним механізмом $з$ використанням метану $i$ гідроксильних радикалів. Метан та пероксид гідрогену подаються у кавітаиійне поле. Головними продуктами реакиії $\epsilon$ метанол $i$ вода. Розраховано ступінь перетворення метану, який дорівнює $\sim 10 \%$.

Ключові слова: активація метану, гідроксильний радикал, метильний радикал, кавітаиія, синтез метанолу. 